\title{
Uzurpacja prestiżu na przykładzie Magdalenki
}

\section{Usurpation of prestige. Case of Magdalenka}

\author{
Mariusz KOWALSKI \\ Instytut Geografii i Przestrzennego Zagospodarowania PAN \\ ul. Twarda 51/55, 00-818 Warszawa \\ mar.kow@twarda.pan.pl
}

Zarys treści: Ograniczenia prawne i finansowe powodują, iż nie każdy może zamieszkać w prestiżowym miejscu. Z tego powodu pojawiają się inicjatywy instytucjonalne i budowlane, które powołując się na renomę danej miejscowości, są realizowane poza jej granicami lub w sposób odbiegający od dotychczasowych tradycji. Rozwiązania te prowadzą do nieuchronnych przekształceń w zagospodarowaniu przestrzennym, bardzo często zmieniając dotychczasowy charakter wielu miejscowości. Jednym z przykładów tego zjawiska może być podwarszawska Magdalenka i jej okolice. Zaprojektowana jako osiedle-las, zabudowana była do tej pory pojedynczymi i zróżnicowanymi domami jednorodzinnymi. Ostatnio powstają tu jednak zunifikowane osiedla, których istotną cześć stanowi zabudowa bliźniacza. Poza granicami Magdalenki powstają osiedla o jeszcze większej intensywności zabudowy, najczęściej na bezleśnych obszarach, jednak także uzurpujące sobie renomę legendarnej sąsiadki. W rezultacie prowadzi to do nieuchronnej zmiany charakteru wszystkich sąsiadujących miejscowości, wpływając również na tożsamość lokalną ich mieszkańców.

Słowa kluczowe: Magdalenka, miasto-ogród, prestiż, zasoby lokalne, rozwój.

\section{Wstęp}

Podstawą rozwoju lokalnego są zasoby, jakimi dysponują społeczności i które tworzą kapitał terytorialny danej jednostki (Przygodzki 2015). Te zasoby można rozumieć bardzo szeroko: zasoby przyrodnicze (surowce mineralne, biosfera), ludzkie (jakościowe i ilościowe), gospodarcze, społeczne, infrastrukturalne, dogodna lokalizacja itd. Do zasobów, jakimi dysponuje dana jednostka terytorialna, można niewątpliwie zaliczyć także jej wizerunek utrwalony w świadomości społecznej. Niektóre miejsca uznawane są za szczególnie atrakcyjne i prestiżowe, inne cieszą się niezbyt pochlebną sławą. Pozostałe kojarzą się neutralnie lub trudno o nich cokolwiek powiedzieć. Opinie te budujemy na podstawie ogólnej wiedzy, często bardzo subiektywnej, dotyczącej zasobów danej miejscowości (Dewalska-Opitek 2010). W ten sposób sama opinia staje się jednym z zasobów (jako swoisty trademark), na którym opierany jest rozwój miejscowości. Potrafi ona żyć swoim własnym życiem, często w oderwaniu od rzeczywistej sytuacji. Nic więc dziwnego, iż wizerunek miejscowości bardzo często poddawany jest zabiegom o charakterze marketingowym, 
W celu budowania, podtrzymania lub wzmocnienia dobrej opinii o danym miejscu (Cai 2002; Hanna i Rowley 2011; Hulicka 2014; Glińska 2016).

Pozytywna opinia o danej miejscowości czyni ją atrakcyjną i skłania ludzi do spędzania tam wolnego czasu, nabywania nieruchomości lub trwałego osiedlenia się (Servillo i in. 2012). W ten sposób część prestiżu związanego z atrakcyjnym miejscem staje się również ich udziałem. W ślad za pionierami podążają następni, chcący również dołączyć do elitarnego grona. Takimi znanymi na całym świecie miejscami są np. Beverly Hills lub Miami Beach w Stanach Zjednoczonych czy też Monte Carlo, San Remo, czy Brighton w Europie. Takie miejsca znaleźć można we wszystkich zakątkach świata, choć ich ranga może być różna. Jedne mają znaczenie międzynarodowe, inne krajowe, jeszcze inne regionalne lub tylko lokalne. W przypadku Polski do tego typu miejsc zaliczyć można modne kurorty (Zakopane, Sopot, Jurata, Międzyzdroje), dzielnice niektórych miast (Saska Kępa czy Stary Żoliborz w Warszawie) oraz liczne podmiejskie osiedla (małe miasteczka) bardzo często łączące funkcje rezydencjalne z rekreacyjno-wypoczynkowymi (np. Puszczykowo, Podkowa Leśna).

Celem niniejszego opracowania jest odpowiedź na pytanie, jak prestiż Magdalenki znanej miejscowości rezydencyjno-letniskowej, wpływa na jej rozwój oraz na rozwój miejscowości sąsiednich, korzystających niejako z jej „aury”. Interesujące będzie również, czy te zależności mogą działać w drugą stronę, czyli jak rozwój sąsiednich miejscowości może wpływać na wizerunek i rozwój samej Magdalenki. Czy występuje sprzężenie zwrotne, i jakie są jego skutki dla rozwoju lokalnego. Analiza dotyczy przede wszystkim inwestycji mieszkaniowych, gdyż są one najbardziej widoczne na badanym obszarze. Funkcje mieszkaniowe są cechą charakterystyczną Magdalenki, a na jej wzór i podobieństwo przejmują je, choć z różnym skutkiem, także sąsiednie miejscowości. Celem badania jest również odpowiedź na pytanie, czy zasób lokalny w postaci marki znanej podwarszawskiej miejscowości spełnia pozytywną rolę czy też, w określonych okolicznościach, może stać się źródłem zagrożeń dla rozwoju lokalnego.

W odniesieniu do przedstawionych celów przeanalizowano najpierw koncepcję miasta-ogrodu, która legła u podstaw popularności wielu polskich miejscowości, a następnie koncepcję rozwoju samej Magdalenki, jako szczególnego przypadku realizacji i funkcjonowania miasta-ogrodu (osiedla-lasu). W celu wykazania, jak inwestycje wpływają na zagospodarowanie badanego obszaru, przeanalizowano historię dużych inwestycji mieszkaniowych w ostatnich latach tak w Magdalence, jak w sąsiednich miejscowościach. Opracowanie kończy analiza zagadnienia, czy Magdalenka spełnia rolę zasobu przyciągającego inwestorów, i czy te ewentualne inwestycje mają pozytywny wpływ na rozwój miejscowości i jej otoczenia.

\section{Miasta-ogrody w Polsce}

W polskich warunkach miano atrakcyjnych i prestiżowych miejscowości rezydencjalnych uzyskało wiele miejscowości, które rozwinęły się w nawiązaniu do koncepcji „miasta-ogrodu". Do dziś wiele z nich opiera na tej idei swoją trademark (Hulicka 2014). Wspomniana idea pojawiła się w końcu XIX w. za sprawą E. Howarda (1898), który w swej rozprawie To-morrow: a peaceful path to real reform, postulował poprawę jakości życia mieszkańców poprzez połączenie pozytywnych cech miast (dostęp do pracy i usług) i obszarów wiej- 
skich (zieleń, świeże powietrze, mniej intensywna zabudowa). Idea ta przyjęła się również w Polsce, przybierając jednak swoje szczególne cechy. Polskie miasta-ogrody, poza nielicznymi wyjątkami, zakładano na terenach leśnych należących do wielkiej własności ziemskiej. W odróżnieniu od innych miast-ogrodów, np. Hellerau koło Drezna, New Earswick koło Yorku, w Polsce koncepcja Howarda przybierała najczęściej postać typowych osiedli mieszkaniowych, oddalonych od obszarów przemysłowych i wielkomiejskich. Walory ekologiczne i zdrowotne miały zachęcić społeczeństwo do osiedlania się na tych terenach. W stosunku do pierwotnej koncepcji miasta-ogrodu nie były one samowystarczalne ekonomicznie, lecz uzależnione od metropolii. Hasło „Mieszkaj na wsi, pracuj w mieście” było reklamą miast-ogrodów na początku XX wieku. Kolejną cechą wyróżniającą polskie osiedla była własność prywatna, gdyż w brytyjskim pierwowzorze stosunki własnościowe rozwiązywano w formie samorządowej, spółdzielczej lub patronackiej. W Polsce nastawiono się na sprzedaż działek pod budownictwo indywidualne. Nowi właściciele byli zobowiązani do przestrzegania standardów ekologicznych (np. min. 30\% działki musi być zadrzewione), budowlanych, użytkowych. Zasady te wynikały początkowo nie z prawa lokalnego, ale z warunków sprzedaży (Szczęśniak 2012).

Charakterystyczne dla Polski uwarunkowania sprawiły, iż miasta-ogrody uzyskały szczególnie elitarny charakter. Można to prześledzić na przykładzie podwarszawskich miejscowości: Podkowy Leśnej i Zalesia Dolnego. Nieruchomości kupowały tu osoby zamożne, traktując je jako letnie rezydencje. Dopiero z biegiem czasu właściciele osiedlali się na stałe. Lecz nie tylko pieniądze decydowały o specyfice społeczności. W jej szeregach znajdowało się szczególnie dużo osób należących do szeroko rozumianych elit politycznych, artyści, reprezentanci wolnych zawodów, czyli szeroko rozumiana inteligencja. Prezentowali wysoką kulturę i odwagę myślenia, przyczyniając się do budowy szczególnego charakteru miejscowości (Szczęśniak 2012).

Prócz Podkowy Leśnej i Zalesia Dolnego do idei tej nawiązywały w Polsce, i wciąż w dużym stopniu nawiązują, takie miejscowości/osiedla jak: Milanówek, Puszczykowo, Giszowiec, Żoliborz Oficerski, Komorów, Sokolniki, Ząbki (Szczęśniak 2012; Hulicka 20014). Ich walory jako miasta-ogrodu wykorzystywane są również bardzo często w celach promocyjnych. Adresatami tych akcji są mieszkańcy dużych miast, którzy tęsknią za spokojem i zielenią (Hulicka 20014).

\section{Miasto-las Magdalenka}

Idea miasta-ogrodu przyświecała niewątpliwie powstaniu podwarszawskiej Magdalenki i jest ona zaliczana do tej kategorii przez specjalistów (Kraina miast-ogrodów... 2016), choć jego pomysłodawcy używali określenia „miasto-las” (Buchalczyk 2002), które niewątpliwie bardziej oddawało charakter planowanej miejscowości. Nie wyłamuje się to jednak z ogólnej idei miasta-ogrodu, i znajduje analogię z podłódzkim miastem-ogrodem Kolumną, które również było reklamowane jako miasto-las (Baranowska 2008).

Do lat 30. XX w. Magdalenka była folwarkiem obejmującym mało urodzajne, piaszczyste, grunty, w dużym stopniu zalesione i pokryte wydmami. Właściciele niedogodności te postanowili przekształcić w atut, przeznaczając folwark pod parcelację, objętą jednolitym planem miasta-ogrodu. Oferta sprzedaży została skierowana do warszawiaków pragnących uciec od miejskiego zgiełku, nie rezygnując jednocześnie z bliskości Warszawy (Bu- 
chalczyk 2002). Znaczną część pionierów stanowili pracownicy warszawskich banków oraz inne osoby mające stabilne dochody i dostęp do kredytów (Beer 2006a, b). Okoliczności te legły niewątpliwie u podstaw elitarnego charakteru Magdalenki. Po II wojnie światowej miejscowość tę upodobali sobie komunistyczni dygnitarze. Wymienia się w tym kontekście m.in. Franciszka Szlachcica, Mieczysława Moczara, Michała Żymierskiego, Franciszka Kaima (Magdalenka...). Ich obecność sprzyjała niewątpliwie wzmacnianiu przekonania o prestiżowym charakterze miejscowości.

W obecnym czasie dowodów na elitarny charakter Magdalenki dostarcza m.in. geografia wyborcza. Na tle sąsiednich obwodów wyborczych z gmin Raszyn i Lesznowola miejscowość wyróżnia się największym poparciem dla partii o charakterze liberalnym (Platforma Obywatelska i.Nowoczesna - ryc. 1), które kojarzone są w literaturze jako reprezentanci interesów elit społecznych i gospodarczych (Bański i in. 2009).

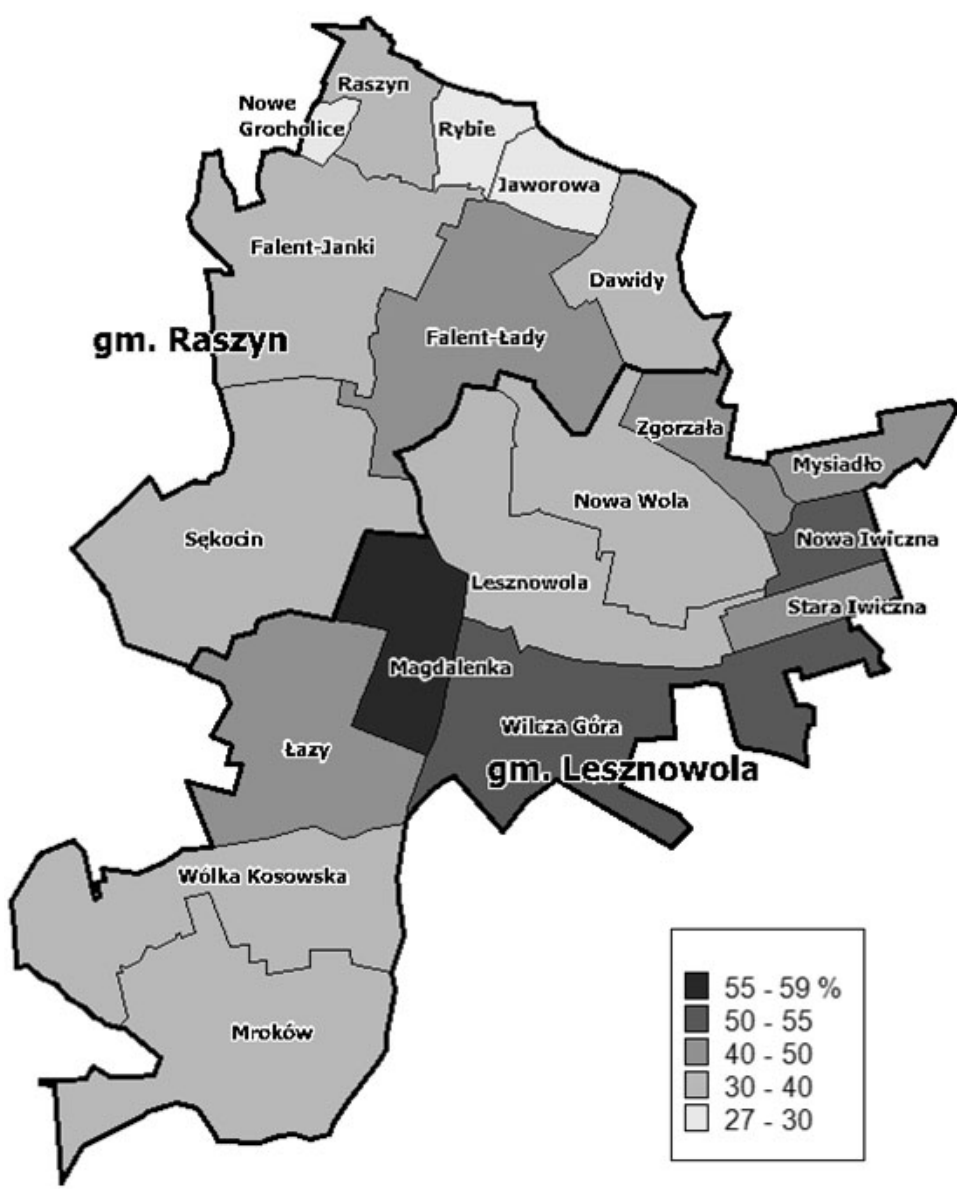

Ryc. 1. Poparcie dla opcji liberalnej (Platforma Obywatelska i.Nowoczesna) w obwodach wyborczych gmin Lesznowola i Raszyn w wyborach do Sejmu 2015 r.

Źródło: opracowanie własne.

Support for the liberal option (Platforma Obywatelska and Nowoczesna parties) in the election districts of the Lesznowola and Raszyn communes in the parliamentary elections of 2015

Source: own elaboration. 
Projekt miejscowości zakładał zagospodarowanie całości obszaru byłego folwarku. Obok działek leśnych przeznaczonych pod zabudowę indywidualną przewidziano obiekty użyteczności publicznej: kościół, szkoły, kasyno, boisko, basen, straż pożarną, cmentarz, itp. Wybuch wojny uniemożliwił realizację większości z tych zamierzeń. Nie sprzedano również dużej części wydzielonych już działek. Z tego powodu osiedle nie uzyskało przedstawionego w pierwotnym projekcie kształtu, jednak jego powstanie stało się faktem. Powstały dwa skupiska domów, jedno na północy, drugie na południu terenów dawnego folwarku, rozdzielone niezagospodarowanym lasem. Ten ostatni, pomimo wydzielonych hipotecznie działek, został w czasach władzy komunistów odebrany właścicielom i włączony pod administrację Lasów Państwowych. Formalnie więc przestał być częścią osiedla (sołectwa).

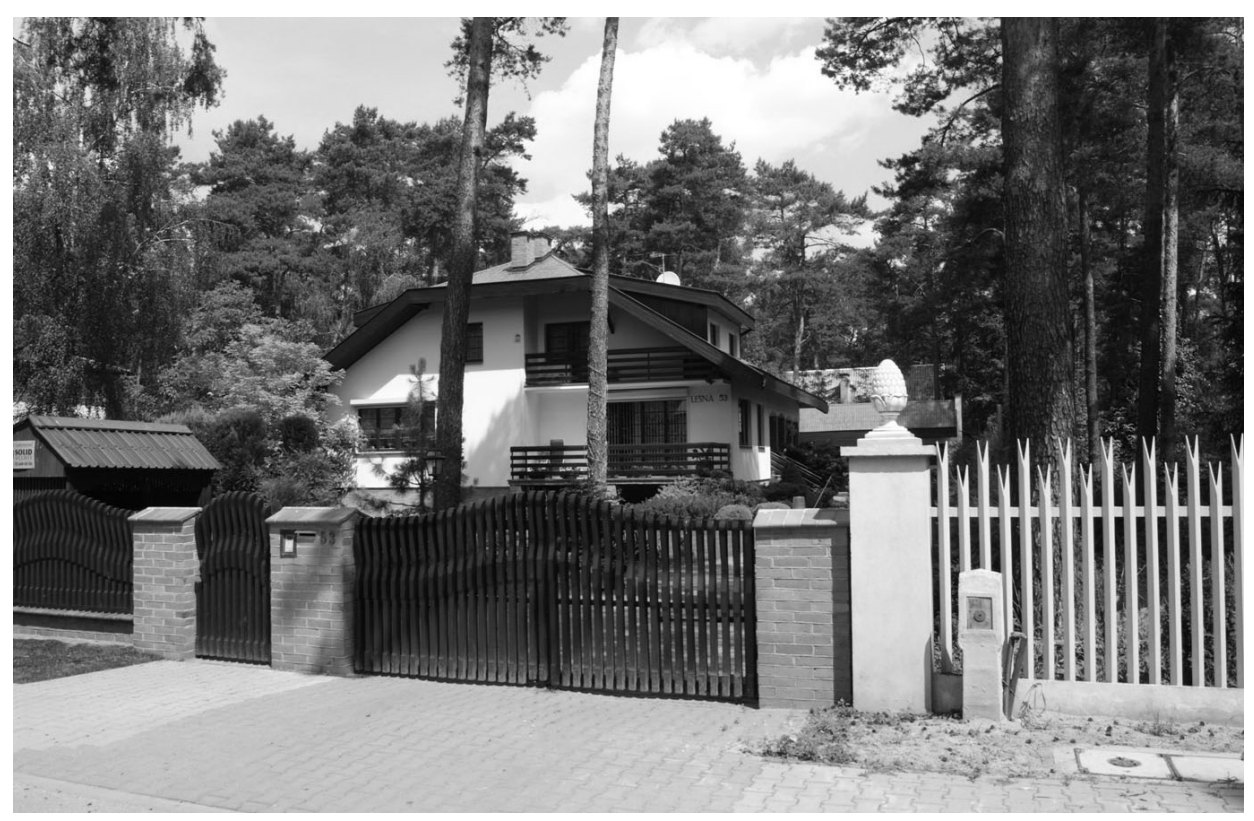

Ryc. 2. Willa w starszej części Magdalenki (fot. M. Kowalski) A villa in the older part of Magdalenka (photo by M. Kowalski)

Pomimo niedokończenia pierwotnego projektu Magdalenka uzyskała atrakcyjną formę urbanistyczną (ryc. 2). Na podstawie pierwotnych założeń każda działka w części północnej osiedla miała liczyć ok. 1800 m² (działki typowo leśne), w części południowej ok. $1200 \mathrm{~m}^{2}$ (działki z ogrodami). Dla działek leśnych ustalono, iż pod zabudowę indywidualną można wyciąć jedynie 21\% drzewostanu, a budynki nie mogą liczyć więcej niż dwie kondygnacje (Buchalczyk 2002). Zbliżone zasady znajdują się również w obecnie obowiązującym miejscowym planie zagospodarowania przestrzennego (Uchwała nr 45/V/2011... 2011). Widać tu dążenie władz lokalnych do zachowania unikalnego charakteru miejscowości. Dzięki temu Magdalenka utrzymuje swój charakter miasta-ogrodu, w jego leśnej odmianie (miasto-las), stając się atrakcyjnym miejscem zamieszkania i odpoczynku. Podobny charakter zachowuje sąsiadujący z Magdalenką Sękocin Las, stąd bardzo często postrzegane są one jako jedna funkcjonalna całość (Buchalczyk 2002). 


\section{Legenda Magdalenki}

Szczególne znaczenie dla rozpoznawalności Magdalenki miały wydarzenia polityczne. Stało się tak za sprawą poufnych rozmów, jakie w ośrodku MSW "Magdalenka” (w rzeczywistości usytuowanym tuż za granicą Magdalenki w Sękocinie-Las) od września 1988 r. prowadziła strona rządowa z gen. Cz. Kiszczakiem na czele z reprezentantami opozycji skupionymi wokół L. Wałęsy. Ich legenda narodziła się już podczas rozmów „Okrągłego Stołu” i trwa do dnia dzisiejszego. Wielu publicystów i polityków uważa, że zawarto tam tajne porozumienie, które zapewniło postkomunistom i liberalnej części strony solidarnościowej dominującą rolę w IV Rzeczpospolitej. Choć rozmowy te odbywały się w różnych miejscach, to właśnie „Magdalenka” stała się hasłem określającym niezbyt przejrzyste momenty w ustalaniu zasad zmiany systemu politycznego i gospodarczego w Polsce (Dubiński 1990; Magdalenka symbolem... 2014).

Pozytywne i negatywne skojarzenia mają ogromną rolę w kreowaniu wizerunku miejscowości (Kostaszuk-Romanowska 2011). A. Czerny (2011) uważa, iż takie nazwy miejscowe jak Jałta, Magdalenka, Targowica, służą jako nośniki negatywnych konotacji (zdrady, służalczości, spisku). Obok roli indeksacyjnej (wskazując konkretny przedmiot) mają więc również znaczenie symboliczne (przywołujące nasze myśli i wyobrażenia). Nie wydaje się jednak, by te negatywne uczucia miały dotyczyć samej miejscowości. Rozmowy kojarzone z Magdalenką stały się raczej elementem budowania jej legendy jako miejsca, w którym odbywały się poufne, tajemnicze i znaczące spotkania na najwyższym szczeblu. Miały więc dla niej raczej pozytywne znaczenia, wzmacniając jej prestiż i atrakcyjność. Natomiast hasło „Magdalenka” zaczęło żyć swoim własnym życiem, stając się nazwą dla wyjątkowego zjawiska politycznego. Jest ono z pewnością kojarzone z Magdalenką, jako miejscem rozmów, ale z nią nieutożsamiane. Podobnie zapewne możemy oceniać przypadek Jałty.

W przypadku Magdalenki jej polityczna legenda odgrywa zapewne większą rolę w promocji osiedla niż uświadamiane walory miasta-ogrodu. Znajduje to m.in. odzwierciedlenie w działaniach miejscowego samorządu, który podkreślając wyjątkowy - z uwagi na walory środowiskowe - charakter Magdalenki, nie odwołuje się jednak do idei miasta-ogrodu, podkreśla natomiast bogactwo historycznych tradycji, na czołowym miejscu stawiając rozmowy z lat 1988-1989 (Plan odnowy miejscowości Magdalenka... 2010). Najwyraźniej tego typu promocja, by utrzymywać przekonanie o atrakcyjności i prestiżu, nie jest osiedlu potrzebna. Magdalenka wydaje się stanowić markę samą w sobie, i nie musi odwoływać się do jakichś ogólnych tożsamości. Nie zaprzecza to jednak możliwości zakwalifikowania jej do kategorii miasta-ogrodu.

Wyjątkowy i prestiżowy charakter miejscowości odzwierciedlają różnego rodzaju doniesienia prasowe. Można się z nich dowiedzieć, jak to znani ludzie (np. Piotr Adamczyk, Michał Wiśniewski) kupują, sprzedają lub tracą domy w Magdalence lub jak stają się twarzami realizowanych tam inwestycji mieszkaniowych (Brzostek 2010). Utwierdzają w tym także artykuły opisujące zalety życia w Magdalence (np. Pawlikowska 2007; Gądek 2010). Nic więc dziwnego, że mieszkają bądź mieszkali tu (lub w sąsiednim Sękocinie-Las) znani artyści, dziennikarze, politycy, a o dołączeniu do elitarnego grona marzą także inni, niekoniecznie tak znani i majętni. 


\section{Nowe inwestycje w Magdalence}

To, co dzieje się w zakresie inwestycji mieszkaniowych w Magdalence i jej okolicach, może stanowić kolejne potwierdzenie prestiżu, jakim cieszy się miejscowość. Na obszarze tradycyjnej Magdalenki miejsc pod inwestycje jest niewiele, ich cena jest wysoka i są obłożone szeregiem ograniczeń budowlanych. Nowe możliwości pojawiły się jednak, gdy spadkobiercy dawnych właścicieli rozpoczęli starania o odzyskanie gruntów oddanych w administracje Lasów Państwowych (Frey 1999; Buchalczyk 2002). Na podstawie ugody udało się uzyskać pod budownictwo część tego obszaru. Niektóre działki znalazły się w rękach indywidualnych inwestorów, większość jednak została zakupiona przez dwie duże firmy deweloperskie. W wyniku tego rozwiązania w środkowej części Magdalenki zaczęły powstawać dwa osiedla mieszkaniowe: Sosnowy Park Magdalenka (sosnowypark.pl) i Willa Magdalenka (www.willamagdalenka.pl) (ryc. 3). Ich założenie odbiegało jednak od funkcjonującego już w Magdalence budownictwa. Pragnienie maksymalizacji zysków przy najniższych kosztach doprowadziło bowiem do powstania zunifikowanych osiedli. Ponieważ prawo miejscowe zabrania zabudowy bliźniaczej, inwestorzy zaprojektowali część budynków jako domy jednorodzinne dwulokalowe (prawo budowlane dopuszcza takie rozwiązanie), które pod względem architektonicznym niczym od bliźniaków się nie różni. Część tych domów dodatkowo skupiono po dwa wokół jednego dziedzińca i podjazdu dla samochodów, co spowodowało powstanie swego rodzaju „czworaków”. W osiedlach tych wydzielono kilka sektorów, w których domy uzyskały jednolitą formę architektoniczną. Rozwiązanie to znacząco odbiegało od dotychczasowej tradycji Magdalenki, z jej indywidualną, różnorodną i mniej intensywną zabudową. W ten sposób na osiedlu Sosnowy Park Magdalenka na 46 działkach powstają 32 domy jednorodzinne i 14 pseudobliźniaków, na osiedlu Willa Magdalenka na 57 działkach zaplanowano i większości już wybudowano 21 domów jednorodzinnych, 18 „czworaków” i 3 pseudobliźniaki (ryc. 4).

Podobny charakter mają dwa osiedla wybudowane w północnej części Magdalenki: Słoneczna Magdalenka (http://www.magdalenka.emmerson.pl/galeria.html) i Leśna Magdalenka (www.verano-konwektor.pl/apartamenty/180-lesna-magdalenka.html). Trzecie z planowanych osiedli - Magdalenka Palaces - nie zostało zrealizowane (ryc. 3). Inwestycje powstawały na obszarze, który w pierwotnym (przedwojennym) projekcie osiedla, nie miał być zagospodarowany. Tu również zabudowę zdominowały zunifikowane domy w zabudowie bliźniaczej.

Wielu osobom te okoliczności nie przeszkadzają. Istotną rolę odgrywa czynnik finansowy, gdyż dom-pseudobliźniak jest tańszy niemal o połowę o tradycyjnego domu w Magdalence. Oferta skierowana była więc w dużej części do osób, których nie stać było na kupno nieruchomości w starej części Magdalenki. Płacąc mniej, nabywca uzyskiwał prestiż zamieszkiwania w atrakcyjnej miejscowości, choć jakość domostwa odbiegała od typowych rezydencji Magdalenki. O tej różnicy przekonał się podobno znany polski aktor, gdy zakupił jeden z nowo wybudowanych bliźniaków. Jego żona miała narzekać na brak intymności i aktor został zmuszony do wystawienia domu na sprzedaż (Piotr Adamczyk...).

Inwestycje ostatnich lat stworzyły tym samym nową jakość w ramach Magdalenki. Nowi mieszkańcy nabyli prawo uważania się za mieszkańców prestiżowej miejscowości, jednak to co osiągnęli, można nazwać uzurpacją prestiżu. Nie tylko dlatego, że ich domostwa odbiegają od wzorca przyjętego tradycyjnie w Magdalence, ale także dlatego, że nowe budynki, zajmując dużą część miejscowości, nieodwracalnie zmieniły jej charakter. 


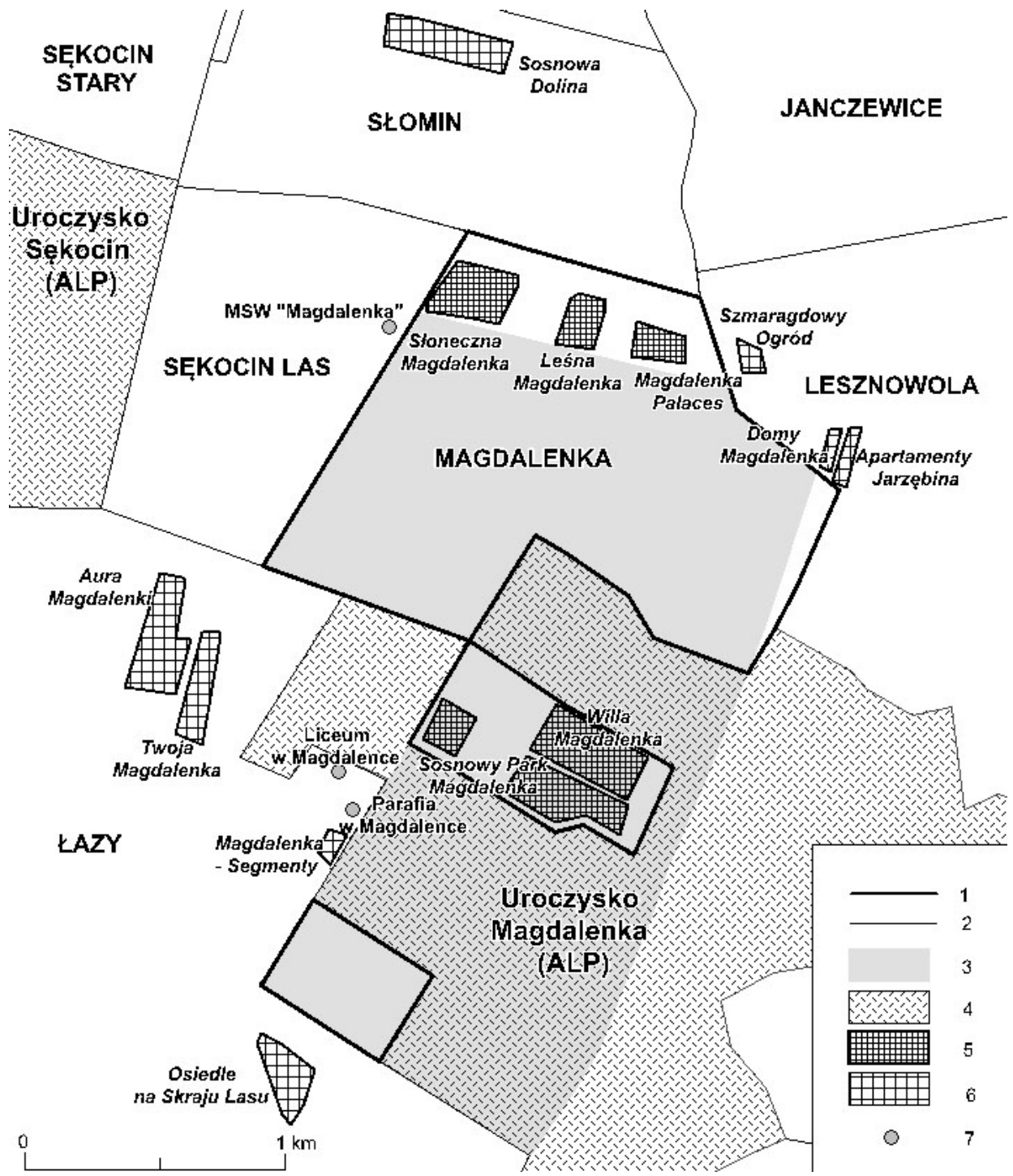

Ryc. 3. Nowe inwestycje mieszkaniowe w Magdalence i jej sąsiedztwie

1 - granice Magdalenki, 2 - granice innych sołectw, 3 - obszar Magdalenki według pierwotnego projektu,

4 - obszary w administracji Lasów Państwowych (ALP), 5 - nowe inwestycje mieszkaniowe na obszarze Magdalenki, 6 - nowe inwestycje mieszkaniowe w sąsiedztwie Magdalenki, 7 - inne obiekty.

Źródło: opracowanie własne.

New housing developments in Magdalenka and in its neighbourhood

1 - Boundaries of Magdalenka, 2-Boundaries of other villages, 3 - Area of Magdalenka according to the initial design, 4-Areas administered by the State Forest Agency (ALP), 5 -New housing projects in the Magdalenka area, 6-New housing projects in the neighbourhood of Magdalenka, 7-Other sites.

Source: own elaboration. 


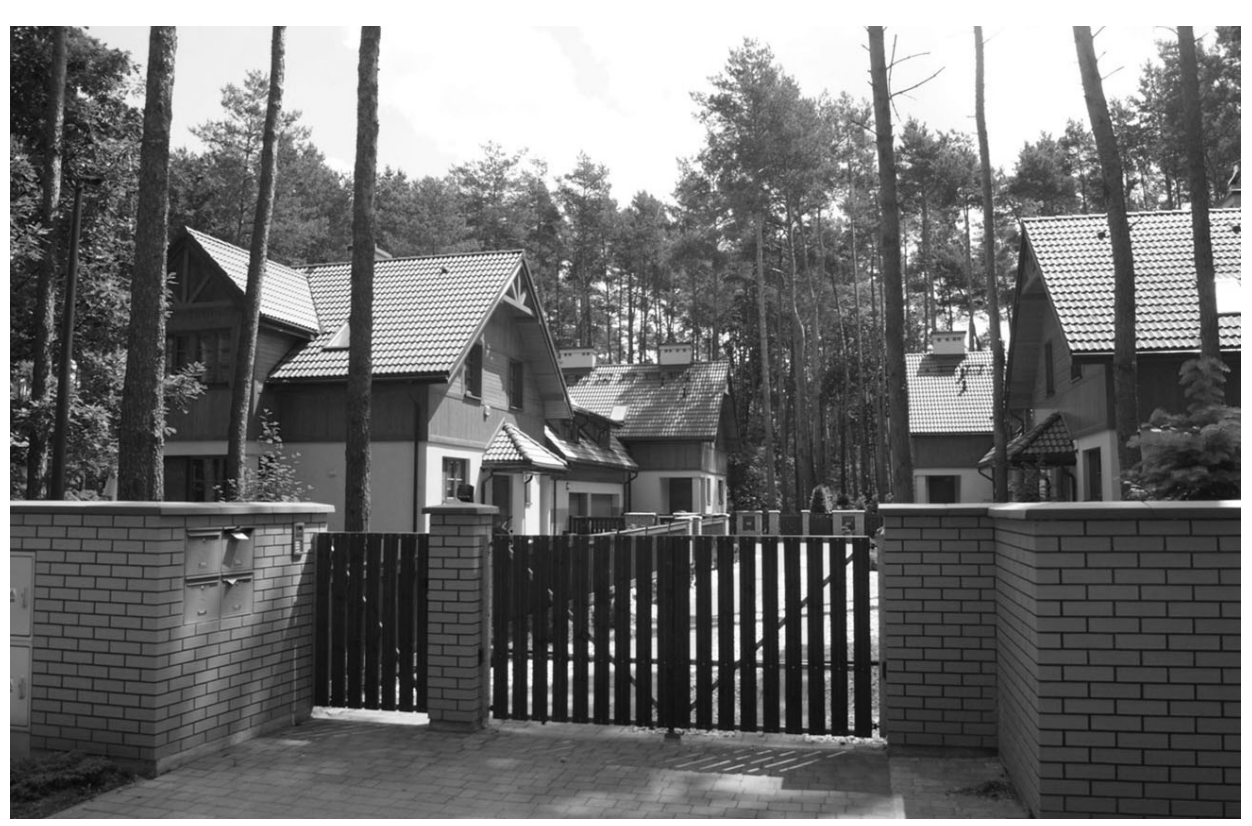

Ryc. 4. „Czworaki” w osiedlu Willa Magdalenka w Magdalence (fot. M. Kowalski)

The "quadruples" in the housing estate "Villa Magdalenka" in Magdalenka (photo by M. Kowalski)

\section{Nowe inwestycje w sąsiedztwie Magdalenki}

Przebiegli developerzy idą jednak znacznie dalej w uzurpowaniu sobie prestiżu Magdalenki. Domy w Magdalence, także w jej nowej części, są zbyt drogie dla przeciętnego nabywcy. Wpływ na cenę ma duża wielkość działek, ograniczenia budowlane oraz atrakcyjność miejscowości. Inaczej jest w sąsiednich miejscowościach, gdzie grunty są tańsze, a prawo miejscowe mniej restrykcyjne. Zachęca to wielu developerów do podszywania się pod prestiż Magdalenki, choć ich inwestycje lokowane są już poza jej granicami. Legendarna nazwa ma niewątpliwie przyciągnąć zdezorientowanych klientów. Zjawisko to obserwowane jest w sąsiedniej Lesznowoli, Łazach i Słominie.

Na obszarze wsi Łazy powstały już dwie inwestycje swoją nazwą nawiązujące ewidentnie do sąsiedniej miejscowości: „Magdalenka Rezydencje” (wcześniej „Twoja Magdalenka” i „Magda i Lenka”) oraz „Aura Magdalenki” (ryc. 3). Nie tylko nie znajdują się one w Magdalence, ale swym zunifikowaniem, intensywnością zabudowy i brakiem lasu, w żaden sposób nie przypominają jej stylu (ryc. 5). Pomimo tego inwestorzy sugerują w materiałach promocyjnych, że osiedla powstają w Magdalence (magdalenkarezydencje.pl; www. auramagdalenki.pl/). Tak samo reklamowane jest ostatnio osiedle segmentów (www.pyzeldev.com/magdalenka-a.htm), choć teren pod planowaną inwestycję także znajduje się w Łazach. W podobny sposób czynią również pomysłodawcy "Osiedla na Skraju Lasu”, gdyż jej adres przedstawiają w postaci Magdalenka/Łazy (www.emeralddevelopment.pl/ inwestycje), jakby nie mogąc się zdecydować, gdzie ona jest rzeczywiście usytuowana. Podobne zjawisko obserwować można także u drugiego sąsiada Magdalenki, w Lesznowoli (ryc. 3). Jedna z firm wybudowała osiedla „Domy Magdalenka” i „Apartamenty Jarzębina”, 
zaś obecnie realizuje kolejne inwestycje: „Osiedle Szmaragdowe” i „Osiedle przy Lesie”. Według materiałów promocyjnych (http://www.domymagdalenka.pl/) wszystkie one zlokalizowane są w Magdalence, jednak w rzeczywistości znajdują się w Lesznowoli, a ich styl architektoniczny i intensywność zabudowy znacznie odbiega od standardów Magdalenki (nawet tej nowej).

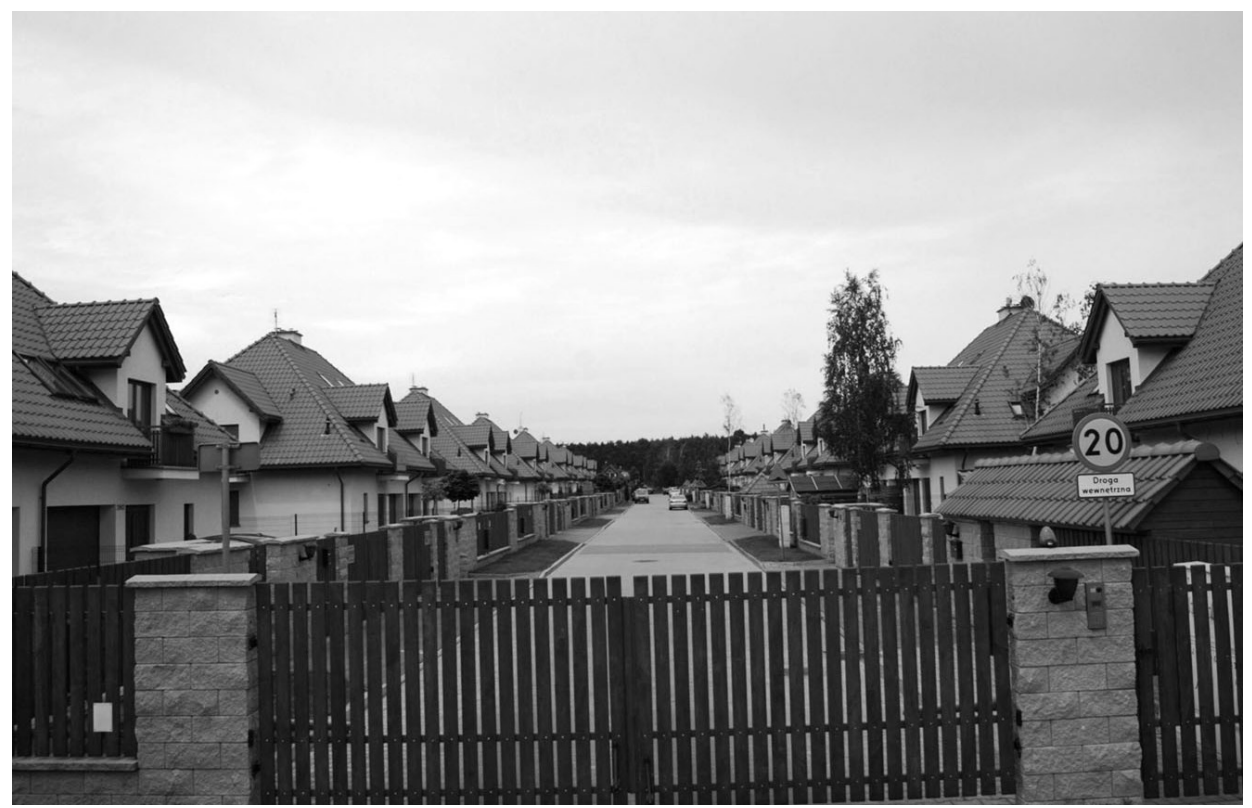

Ryc. 5. Zabudowa osiedla „Aura Magdalenki” w Łazach (fot. M. Kowalski) "Aura of Magdalenka" housing estate in Łazy (photo by M. Kowalski)

Przykładem przekroczenia wielu zasad w imię spodziewanego zysku jest projekt inwestycji na działkach w miejscowości Łazy (ryc. 6), usytuowanych tuż przy kościele parafii rzymskokatolickiej w Magdalence (www.pyzeldev.com/magdalenka-a.htm). Wykorzystując prestiżowe sąsiedztwo, inwestor informuje w materiałach promocyjnych, że inwestycja zlokalizowana jest w Magdalence. Nie zachęca go to bynajmniej do przyjęcia obowiązujących w tej miejscowości standardów, gdyż dąży do wybudowania jak największej liczby obiektów mieszkalnych. Choć obowiązują tu łagodniejsze przepisy budowlane niż w sąsiedniej Magdalence, także i je postanawia ominąć. Pomocne okazują się również decyzje władz lokalnych. Działki położone są na niewielkim fragmencie miejscowości, który jako jedyny wraz z sąsiednią Magdalenką został włączony w skład Warszawskiego Obszaru Chronionego Krajobrazu. Pomimo tego w planie miejscowym wyrażono zgodę, by te właśnie działki mogły mieć minimalną wielkość $800 \mathrm{~m}^{2}$, podczas gdy w pozostałej części wsi Łazy obowiązuje norma 900 m². Dzięki temu właściciel mógł wydzielić ich więcej. Inwestor nie poprzestał jednak na tych preferencjach. Na każdej z działek planuje wybudować dwa domy w zabudowie bliźniaczej, choć wielkość działek nie pozwala już na ich podział, a przecież każdy budynek musi teoretycznie stać na wyodrębnionej geodezyjnie działce. Pomysłowość inwestora idzie jednak dalej, gdyż chce on każdy z bliźniaczych domów podzielić na dwa lokale mieszkalne. W ten sposób na jednej działce chce zbudo- 
wać cztery odrębne segmenty mieszkaniowe. Przy takim rozwiązaniu pojawia się jednak jeszcze jednak okoliczność podważająca legalność inwestycji, gdyż wydzielone na każdej z działek cztery segmenty układają się w zabudowę szeregową (trzy i więcej segmentów mieszkalnych w jednym ciągu), a ta w tej części miejscowości jest zakazana. Można się domyślać, że wybudowanie dwóch domów w zabudowie bliźniaczej na jednej, teoretycznie niepodzielnej działce i wydzielenie w każdym z nich po dwa lokale, wydaje się łatwiejsze do przeforsowania, niż wydzielenie czterech niedozwolonych w domu jednorodzinnym lokali. Być może inwestor ma również nadzieje, że przy takim zagmatwaniu architektoniczno-projektowym powstałe segmenty nie zostaną uznane za zabudowę szeregową. Gdyby tak się stało, byłoby to oczywiście absurdalne z punktu widzenia logiki i sprzeczne z intencjami ustawodawcy, który chciał na tym obszarze ograniczyć, a nie zwiększyć intensywność zabudowy. Byłoby to również ze szkodą dla leśnego charakteru otoczenia kościoła parafii w Magdalence, będącego jedną z wizytówek tej miejscowości. Ale i tym najwyraźniej inwestor nie wydaje się przejmować (Myszyński 2016; Osiedle Leśna Polana...; Uchwała NR 67/VII/2015...; Studium uwarunkowań... 2011; Wojtczuk 2016).

Nieco bardziej umiarkowani są pomysłodawcy i wykonawcy osiedla „Sosnowa Dolina” w sąsiadującym z Magdalenką Słominie (ryc. 3). Co prawda osiedle nie leży ani w dolinie, ani wśród sosen, lecz w szczerym polu, to przynajmniej prawdziwa lokalizacja nie jest ukrywana, niemniej i tutaj przyjmuje ona trochę dziwną formę (Słomin/Magdalenka), tak jakby Słomin był dzielnicą Magdalenki, lub cała inwestycja była realizowana w obu miejscowościach. Tymczasem osiedle oddalone jest od Magdalenki o 1 km, a dodatkowo oddzielone od niej granicami gmin (Raszyn, Lesznowola) i powiatów (pruszkowski, piaseczyński).

Omawiane zjawisko nie dotyczy tylko przedsięwzięć mieszkaniowych. Nazwy Magdalenka używają takie instytucje, jak kompleks usługowo-handlowy „Las Magdalenka”, Parafia rzymskokatolicka w Magdalence (http://www.parafia-magdalenka.pl/), Gimnazjum i Liceum w Magdalence (http://www.popieluszko.org.pl/), a nawet Cmentarz w Magdalence choć wszystkie one usytuowane są w Łazach. W przypadku parafii można to wytłumaczyć tradycją (choć krótkotrwałą), gdyż u swych początków kaplica parafialna została wybudowana na obszarze Magdalenki i pod tą nazwą erygowano w 1934 r. parafię. Kościół parafialny wzniesiono dwa lata później (1936 r.) już jednak na gruntach wsi Łazy. Tam też znajdują się obecnie wszystkie zabudowania parafialne, bo pierwotna kaplica już nie istnieje.

Podobne uwagi można kierować także pod adresem lokalizacji ośrodka MSW, w którym odbywały się poufne rozmowy w latach 1988-1989. Jest on usytuowany na obszarze miejscowości Sękocin Las, lecz jeszcze przed 1988 r. kojarzono go ewidentnie z Magdalenką. Stąd mamy "rozmowy w Magdalence”, a nie „w Sękocinie”.

Opisywane zjawisko przypisywania sobie prestiżu sąsiedniej miejscowości nie jest charakterystyczne tylko dla okolic Magdalenki. Takich miejsc można by w Polsce i na świecie znaleźć prawdopodobnie znacznie więcej. Przykładem może być rezydencja Prezydenta RP na Półwyspie Helskim, która znajduje się w granicach administracyjnych miasta Hel, lecz powszechnie utożsamiana jest z Juratą, gdyż ta ostatnia uważana jest za bardziej prestiżową (Socha 2008). 


\section{MAGDALENKA APARTAMENTY/SEGMENTY BEZCZYNSZOWE OSIEDLE LEŚNA POLANA}

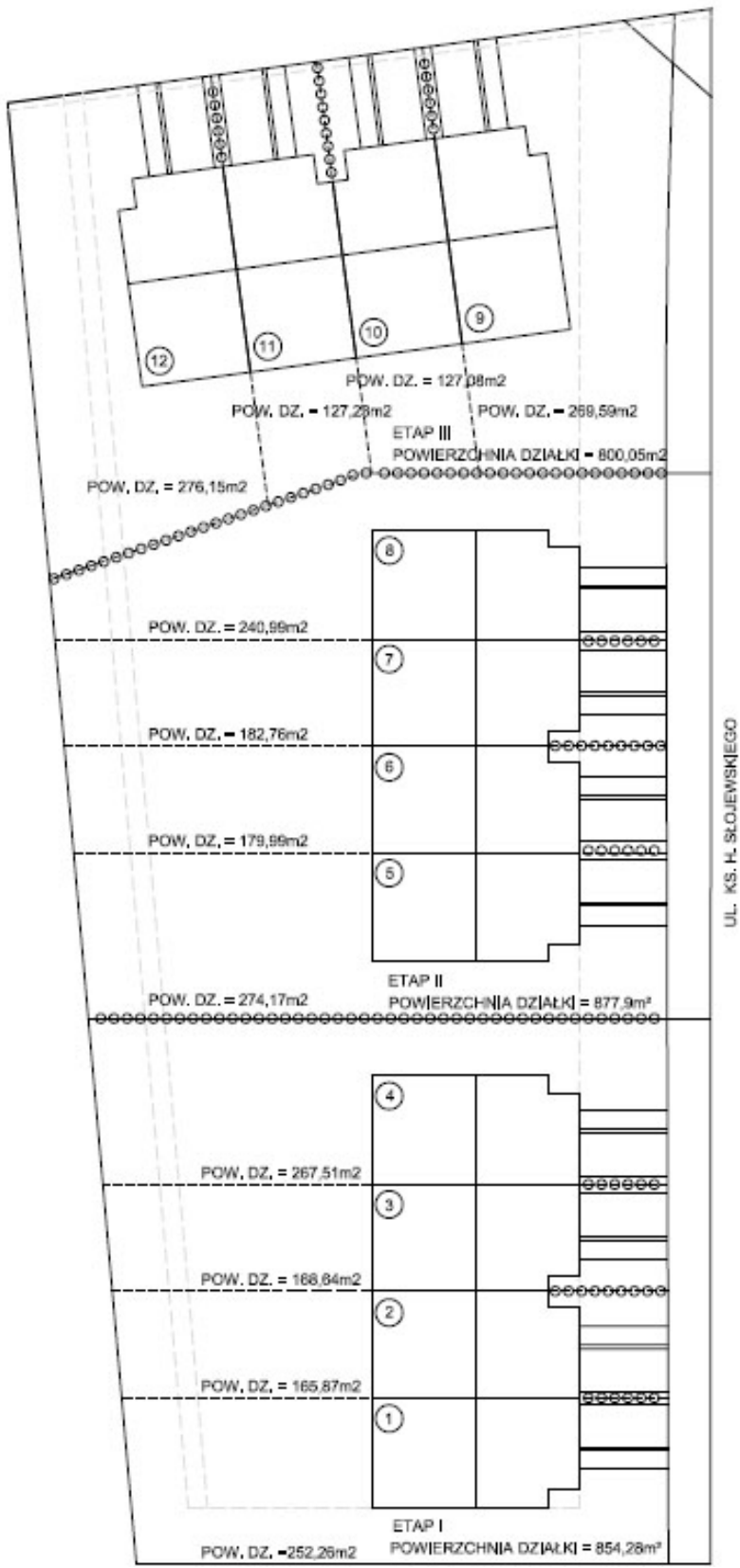

Ryc. 6. Projekt osiedla „Leśna Polana/Magdalenka-segmenty” powstającego w Łazach w sąsiedztwie kościoła parafii w Magdalence

"Leśna Polana/Magdalenka-segments" housing estate in Łazy in the neighborhood of the parish church of Magdalenka

Źródło / Source: www.pyzeldev.com/magdalenka-a.htm 


\section{Wnioski}

Niezależnie od tego, jak wyglądać będzie dalszy rozwój Magdalenki i jej okolic, pewne zjawiska stały się faktem. Po pierwsze, w samej Magdalence powstały nowe osiedla, które swym charakterem odbiegają od dotychczasowych tradycji architektonicznych miejscowości. Tworzą pierwszą kategorię uzurpacji dotychczasowego prestiżu miejscowości. Po drugie, w sąsiedztwie powstały inwestycje sugerujące swym klientom, iż znajdują się na obszarze Magdalenki, choć nawet nie starają się do niej upodobnić stylem zabudowy. Są jeszcze inwestycje, które nie podszywają się pod Magdalenkę, a jedynie informują o jej sąsiedztwie, jako atucie. Tutaj trudno mówić o uzurpacji, choć i tu przeważa najwyraźniej przekonanie, iż Magdalenka jest czymś cenniejszym niż proponowana lokalizacja.

Na podstawie opisanych przykładów widać, iż adres w Magdalence uzurpują sobie obiekty znajdujące się we wszystkich sąsiadujących z nią miejscowościach. Można to uznać za jeszcze jedno potwierdzenie jej atrakcyjności i prestiżu. Pojawia się jednak pytanie, jaki wpływ obserwowane procesy mogą mieć dla rozwoju lokalnego. Z jednej bowiem strony pojawia się niebezpieczeństwo rozmywania się tożsamość Magdalenki wśród nowych elementów rzeczywistości. Z drugiej zaś strony może następować osłabienie spójności miejscowości sąsiednich, jeżeli mieszkańcy niektórych z ich fragmentów będą dążyli do utożsamiania się z inną miejscowością. Czy ten potencjalny scenariusz należałoby uznać za coś oczywistego i nieuchronnego, czy też powinno się mu w jakiś sposób przeciwdziałać? Na te pytania powinni sobie niewątpliwie odpowiedzieć planiści, władze lokalne, a przede wszystkim inwestorzy.

Należy również zwrócić uwagę, iż z jednej strony obecność Magdalenki jest zasobem lokalnym okolicy, elementem miejscowego kapitału terytorialnego, przyciągającym inwestorów, przedsiębiorców i nowych mieszkańców. Z drugiej jednak strony, ich napływ prowadzi do nieodwracalnych zmian w zagospodarowaniu przestrzennym, wpływając tak na oblicze samej Magdalenki (intensywna i ujednolicona zabudowa nowych osiedli), jak i jej otoczenia (powstawanie wianuszka intensywnej i ujednoliconej zabudowy wokół Magdalenki). Wydaje się, iż rozwiązanie problemów można znaleźć poprzez próby godzenia dotychczasowego charakteru tutejszych miejscowości z wymogami rozwojowymi poprzez regulowanie niektórych zjawisk. Dotychczasowa praktyka wskazuje jednak, że tego typu polityka lokalna nie została jeszcze uruchomiona. Jeżeli ta sytuacja będzie się utrzymywać, istnieje niebezpieczeństwo, iż Magdalenka i jej otoczenie staną się karykaturą swego dotychczasowego stanu, co spowoduje utratę atrakcyjności i prestiżu.

\section{Literatura}

Bański J., Kowalski M., Mazur M., 2009, Zachowanie wyborcze mieszkańców polskiej wsi, Przegląd Geograficzny, 81, 4, s. 483-506.

Baranowska M., 2008, Rozwój historyczny podłódzkich Miast-Ogrodów na przykładzie Miasta-Lasu Kolumny, [w:] M. Kulesza (red.), Czas i przestrzeń w naukach geograficznych. Wybrane problemy geografii historycznej, Wydawnictwo UŁ, Łódź, s. 196-203.

Beer J.Z., 2006a, Magdalenka: daty przełomowe w dziejach osiedla - albo od "kawiarenki" do "Sarenki”, [w:] B. Buchalczyk (red.), Magdalenka. Historia - przyroda-ludzie, cz. 2, Urząd Gminy Lesznowola, Stowarzyszenie Miłośników Osiedli Magdalenka i Sękocin, Warszawa, s. 62-89. 
Beer J.Z., 2006b, Przyjaciele - pionierzy, [w:] B. Buchalczyk (red.), Magdalenka. Historia - przyroda - ludzie, cz. 2, Urząd Gminy Lesznowola, Stowarzyszenie Miłośników Osiedli Magdalenka i Sękocin, Warszawa, s. 165-174.

Brzostek D., 2010, Radosław Majdan zareklamuje mieszkania, http://porady.domiporta.pl/poradnik/1,127301,8518443,Radoslaw_Majdan_zareklamuje_mieszkania.html

Buchalczyk B., 2002, Magdalenka. Historia - przyroda - ludzie, Stowarzyszenie Miłośników Osiedli Magdalenka i Sękocin, Warszawa.

Cai L.A., 2002, Cooperative branding for rural destinations, Annals of Tourism Research, 29, 3, s. $720-742$.

Czerny A., 2011, Teoria nazw geograficznych, Prace Geograficzne, 226, IGiPZ PAN, Warszawa.

Dewalska-Opitek A., 2010, Budowanie wizerunku jednostki terytorialnej na przykładzie województwa ślqaskiego, Zarządzanie Publiczne, 4(12), s. 83-98.

Dubiński K., 1990, Magdalenka, transakcja epoki: notatki z poufnych spotkań Kiszczak-Watęsa, Sylwa, Warszawa.

Frey D., 1999, Magdalenka na wokandzie, Rzeczpospolita 1999.08.23.

Gądek J., 2010, Magdalenka. Wieś w lesie otoczona politycznq legendq, http://wiadomosci.onet.pl/ warszawa/magdalenka-wies-w-lesie-otoczona-polityczna-legenda [dostęp: 25.06.2016].

Glińska E., 2016, Budowanie marki miasta. Koncepcje, warunki, modele, Wolter Kluwer, Warszawa.

Hanna S., Rowley J., 2011, Towards a strategic place brand management model, Journal of Marketing Management, 27, 5-6, s. 458-476.

Howard E., 1898, To-morrow: a peaceful path to real reform, Swan Sonnenschein \& Co., London.

Hulicka A., 2014, „Miasto ogród”. Analiza możliwości wykorzystania walorów urbanistyczno-krajobrazowych w promocji miasta i budowaniu jego marki na przykładzie wybranych miast polskich, Polityka i Społeczeństwo 2 (12)/2014, s. 112-124

Kostaszuk-Romanowska M., 2011, Rola pozytywnych i negatywnych skojarzeń w kreowaniu wizerunku miasta, [w:] A. Grzegorczyk, A. Kochaniec (red.), Kreowanie wizerunku miast, Wyższa Szkoła Promocji, Warszawa, s. 163-180.

Kraina miast-ogrodów, portal autorstwa Magdaleny Prosińskiej, http://www.miastaogrody.pl [dostęp: 25.06.2016].

Magdalenka (województwo mazowieckie), https://pl.wikipedia.org/wiki/Magdalenka_\%28wojew\%C3\%B3dztwo_mazowieckie\%29

Magdalenka symbolem przemian. Wystawa, 2014, http://www.gok.lesznowola.pl/upload/Magdalenka\%20symbolem\%20przemian.\%20Wystawa\%202014 [dostęp: 25.06.2016]

Michał Wiśniewski stracił dom w Magdalence, http://www.se.pl/galerie/58223/110785/willa-wisniewskiego-w-magdalence/ [dostęp: 25.06.2016]

Myszyński K., 2016, Magdalenka: Nowa inwestycja mieszkaniowa budzi wątpliwości mieszkańców, http://politykalesznowola.blog.pl/2016/02/25/magdalenka-nowa-inwestycja-mieszkaniowabudzi-watpliwosci-mieszkancow/ [dostęp: 25.06.2016]

Osiedle Leśna Polana - inwestycja na działce parafii w Magdalence, http://www.powiat-piaseczynski.info/lesznowola/63-informacja/8908-osiedle-lesna-polana-inwestycja-na-dzialce-parafii-wmagdalence [dostęp: 25.06.2016]

Pawlikowska B., 2007, W Magdalence, http://z.beatapawlikowska.com/diary, list, 2099,1.html [dostęp: 25.06.2016]

Piotr Adamczyk sprzedaje swojg willę w Magdalence. Kup sobie dom Adamczyka za 1,5 mln, http:// www.se.pl/galerie/83417/163647/kup-sobie-dom-adamczyka/ [dostęp: 25.06.2016] 
Plan odnowy miejscowości Magdalenka w gminie Lesznowola, Załącznik Nr 1 do Uchwały Nr 582/ XLII/2010 Rady Gminy Lesznowola z dnia 9 listopada 2010 roku, http://www.lesznowola.eobip. pl/_gAllery/11/47/11472/582_MAGDALENKA.pdf [dostęp: 25.06.2016]

Przygodzki Z., 2015, Kapitał terytorialny w zintegrowanym planowaniu rozwoju: koncepcje wspótpracy, Barometr Regionalny, 4/13, s. 29-33.

Przybysz A., 2007, Puszczykowo miasto-ogród, Biblioteka Miasta w Puszczykowie, Puszczykowo.

Servillo L., Atkinson R., Russo A.P., 2012, Territorial attractiveness in EU urban and spatial policy: A critical review and future research agenda, European Urban and Regional Studies, 19(4), s. 349-365.

Socha R., 2008, Prezydent za płotem, Polityka, 4 sierpnia 2008, http://www.polityka.pl/tygodnikpolityka/kraj/263600,1,prezydent-za-plotem.read

Studium uwarunkowań i kierunków zagospodarowania przestrzennego Gminy Lesznowola, Załącznik nr 1, 2 i 3 do Uchwały Rady Gminy Lesznowola Nr 30/IV/2011 z dnia 15 marca 2011 r., www. lesznowola.pl/strona-glowna/urzad-gminy/referaty/urbanistyka-materialy/studium [dostęp: 25.06.2016]

Szczęśniak E.M., 2012, Miasto-ogród jako wzorzec kształtowania ładu przestrzennego, Wydział Geodezji i Kartografii, Politechnika Warszawska (praca magisterska).

Uchwała nr 45/V/2011 Rady Gminy Lesznowola z dnia 28 kwietnia 2011r. w sprawie uchwalenia miejscowego planu zagospodarowania przestrzennego gminy Lesznowola dla części obrębu Magdalenka, http://lesznowola.intergis.pl/ [dostęp: 25.06.2016]

Uchwała nr 67/VII/2015 Rady Gminy Lesznowola z dnia 9 kwietnia 2015 roku w sprawie uchwalenia miejscowego planu zagospodarowania przestrzennego gminy Lesznowola dla części wsi Łazy i Wólka Kosowska obszar III, http://lesznowola.intergis.pl/ [dostęp: 25.06.2016]

Wojtczuk M., 2016, Parafia jak deweloper. Mieszkańcy protestuja przeciw budowie na kościelnej działce, http://warszawa.wyborcza.pl/warszawa/1,34862,19712265, parafia-jak-deweloper-mieszkancy-protestuja-przeciw-budowie.html [dostęp: 25.06.2016]

\section{Źródła internetowe}

sosnowypark.pl [dostęp: 18.07.2016]

www.willamagdalenka.pl [dostęp: 18.07.2016]

www.magdalenka.emmerson.pl/galeria.html [dostęp: 18.07.2016]

www.verano-konwektor.pl/apartamenty/180-lesna-magdalenka.html [dostęp: 18.07.2016]

magdalenkarezydencje.pl [dostęp: 18.07.2016]

www.auramagdalenki.pl [dostęp: 18.07.2016]

www.pyzeldev.com/magdalenka-a.htm [dostęp: 18.07.2016]

www.emeralddevelopment.pl/inwestycje [dostęp: 18.07.2016]

\section{Summary}

Due to legal and financial constraints it is impossible for everyone to can live in a prestigious location. Hence the appearance of institutional and construction development initiatives which make appeal to the fame of a particular location, while being realised either outside of this location or in a manner divergent from the tradition to date. Such 
initiatives bring unavoidably the transformations in the spatial organisation, very often changing the previous character of the respective localities.

One of the examples of this kind of processes is a town of Magdalenka near Warsaw. It was designed in the 1930s as a "forest settlement" (a type of "garden-city"), and planned as an area consisting of single, private, diverse family houses. Even though the initial design has never been finalised, the settlement took on an attractive landscape form. Based on the initial prerequisites, every plot in the northern part of the settlement had to be of approximately $1800 \mathrm{~m}^{2}$ (a typical forest construction plot), while in the southern part - approximately $1200 \mathrm{~m}^{2}$ (houses with gardens). For the forest plots it was decided that $21 \%$ of the trees could be cut out during construction, while the buildings should not have more than two floors. These stipulations are in force to this day. Because of the specific character of this locality the first inhabitants were representatives of the Warsaw middle class, and consisted mostly of bank employees. However, after the World War II it was the communist dignitaries that took a liking for Magdalenka, and there is little doubt that this contributed to the strengthening of the conviction as to the prestigious character of the locality.

The development of the fame of Magdalenka was in a special way due to the political events. This was caused by the secret talks that have been conducted here since September 1988 by the communist administration with the representatives of the opposition, grouped around Lech Wałęsa.

The conviction of the exceptional character of Magdalenka had an impact on its attractiveness. Yet, not everyone can afford buying or constructing a traditional home in the locality. For this reasons, new housing estates have been appearing recently in the areas acquired from the State Forest Agency. These estates have a standardised designand are very often twin houses. This lowers the construction costs, thus, reducing the final price of the dwellings as well. Outside of the administrative boundaries of Magdalenka, where construction regulations are less restrictive, housing estates appear, mostly on the forestless areas, with an even higher density of dwellings. The developers of such estates very often take advantage of the name of the legendary neighbouring locality in their promotional materials. This leads to an unavoidable change in the character of all the localities in the neighbourhood, influencing local identity of their inhabitants as well. 